\title{
Targeting tumor cells with antibodies enhances anti-tumor immunity
}

\author{
Zhichen Sun ${ }^{1,2}$, Yang-Xin Fu, ${ }^{1,3}$, Hua Peng ${ }^{1 \bowtie}$ \\ ${ }^{1}$ Key Laboratory of Infection and Immunity, Institute of Biophysics, Chinese Academy of Sciences, Beijing 100101, \\ China \\ ${ }^{2}$ University of Chinese Academy of Sciences, Beijing 100049, China \\ ${ }^{3}$ Department of Pathology, University of Texas Southwestern Medical Center, Dallas, TX 75390, USA
}

Received: 25 May 2018 / Accepted: 23 July 2018 / Published online: 29 October 2018

\begin{abstract}
Tumor-targeting antibodies were initially defined as a group of therapeutic monoclonal antibodies $(\mathrm{mAb})$ that recognize tumor-specific membrane proteins, block cell signaling, and induce tumor-killing through Fc-driven innate immune responses. However, in the past decade, ample evidence has shown that tumor-targeting mAb (TTmAb) eradicates tumor cells via activation of cytotoxic T cells (CTLs). In this review, we specifically focus on how TTmAbs induce adaptive anti-tumor immunity and its potential in combination therapy with immune cytokines, checkpoint blockade, radiation, and enzymetargeted small molecule drugs. Exploring the mechanisms of these preclinical studies and retrospective clinical data will significantly benefit the development of highly efficient and specific TTmAb-oriented anti-tumor remedies.
\end{abstract}

Keywords Tumor antigen, Targeting antibody, Innate immunity, Adaptive immunity, Cytokine, Tumor microenvironment

\section{INTRODUCTION OF CLASSICAL TUMOR-TARGETING ANTIBODIES}

The first generation of tumor-targeting antibodies approved by US Food and Drug Administration (FDA), including trastuzumab, cetuximab, and rituximab, were initially known as signal blockers to target oncogenic receptors of tumor cells and have great potential for effective cancer immunotherapy (Hynes and Lane 2005; Li et al. 2005). Later, Fc receptor (FCR) in immune cells was found to play an essential role in Ab-dependent cell cytotoxicity to tumor cells in vivo (Clynes et al. 2000; Musolino et al. 2008) and Complement-dependent cytotoxicity (CDC) (Teeling et al. 2004; van Meerten et al. 2006). Recently, we and others have reported the function of adaptive immunity in the Ab-mediated tumor regression (Abes et al. 2010; Mortenson et al.

$\bowtie$ Correspondence: hpeng@moon.ibp.ac.cn (H. Peng)
2013; Park et al. 2010; Ren et al. 2017; Stagg et al. 2011; Yang et al. 2013b, 2014). With further understanding of tumor microenvironment (TEM), tumor-targeting $\mathrm{Ab}$ has been used to construct bispecific $\mathrm{Ab}$ and $\mathrm{Ab}-$ cytokine. In combination with checkpoint blockade Abs, radiation therapy, and traditional small molecule chemo- and targeted drugs, TTmAbs can be widely applied to break the immune tolerance and acquired resistance to long-term anti-tumor treatments for the final tumor elimination.

\section{ROLES FOR TUMOR-TARGETING AB TO BRIDGE INNATE IMMUNITY TO CTL}

\section{Anti-HER2 antibody}

The human epidermal growth factor receptor 2 (HER2) is the homologue of the rat neu oncogene (HER2/neu). 
Along with HER1 (EGFR), HER3 and HER4, these proteins belong to the type I growth receptor family (Rajkumar and Gullick 1994). These transmembrane receptors, with molecular weights of approximately 170-185 kDa, are receptor tyrosine kinases that undergo homo- or hetero-dimerization when activated by related ligands (Olayioye et al. 2000; Rajkumar and Gullick 1994; Shepard et al. 2008), but the specific ligand for HER2/neu (ErbB2) is still not identified (Yarden and Pines 2012). This receptor signaling plays essential roles in multiple normal cellular processes of cell proliferation, differentiation, adhesion, motility, and apoptosis (Menard et al. 2003; Quaglino et al. 2008). However, HER2 has been found to be overexpressed in a quarter of breast cancers and is connected to higher malignancy, relapse rates, and mortality (Hudis 2007; Kiessling et al. 2002; Meric-Bernstam and Hung 2006; Slamon et al. 1987). In 1998, the FDA approved trastuzumab (Herceptin) for clinical trial in treating human breast cancer patients. Trastuzumab is a humanized monoclonal antibody containing the complementary regions of the murine antibody (clone 4D5) and Fc region of human IgG1 (Carter et al. 1992; Nahta and Esteva 2006). It binds to HER2 on the cell surface and has been proven to be an effective treatment for HER2/ neu-positive breast cancers in multiple animal studies and clinical trials (Abramson and Arteaga 2011; Hudis 2007; Moasser 2007).

In vitro mechanistic studies have shown that the antiHER2/neu antibody inhibits HER2/neu+ tumor growth, mainly via inducing G1 cell cycle arrest (Le et al. 2005; Mittendorf et al. 2010). Antibody-dependent cellular cytotoxicity (ADCC) is also required for the antitumor effects of anti-HER2 therapy. NK cells induce ADCC after the anti-HER2/neu antibody engagement, resulting in HMGB-1 release and MyD88-dependent TLR stimulation (Clynes et al. 2000; Musolino et al. 2008). Park et al. firstly revealed that the adaptive immune system plays critical roles in anti-HER2/neu-mediated anti-tumor therapeutic effect (Park et al. 2010). They demonstrate that (1) the therapeutic effect of HER2/neu antibody is tumor-specific T-cell dependent; (2) effective antiHER2/neu treatment achieves immune memory that resists the subsequent high dose tumor rechallenge; (3) anti-HER2/neu treatment results in enhanced CD8+ cell infiltration in the tumor tissue of mouse models and clinical patients.

\section{Anti-EGFR antibody}

Epidermal growth factor receptor (EGFR) is another member of the type I growth receptor family. Although HER2 is characterized by lacking an identified ligand,
EGFR has been found to have several other ligands besides EGF, such as transforming growth factor alpha (TGF- $\alpha$ ) (Citri and Yarden 2006; Yarden and Sliwkowski 2001). The first FDA-approved anti-EGFR monoclonal antibodies, including cetuximab (Erbitux, a humanmurine chimeric. Ennis et al. 1991) and panitumumab (a human monoclonal antibody), have been successfully used for the treatment of EGFR-expressing cancers (Yang et al. 2001). These monoclonal antibodies bind to the extracellular domain of EGFR, inhibiting receptor dimerization and downstream signaling (Burgess et al. 2003), and inducing receptor internalization, ubiquitinization, and degradation (Sunada et al. 1986). ADCC and CDC are also the tumor-killing mechanisms resulting from the binding of the monoclonal antibody (Kimura et al. 2007). Primary and acquired resistance becomes increasingly challenging for targeted therapy (Bardelli and Siena 2010; Cobleigh et al. 1999). Ab resistance mediated by mutations within targeted oncogenes or in genes related to oncogenic pathways has been broadly investigated (Misale et al. 2012; Yonesaka et al. 2011). These studies will provide important information for developing drugs that target the increasing intrinsic resistance in tumor cells after antioncogenic $\mathrm{Ab}$ treatment (Bostrom et al. 2009; Fayad et al. 2013; Hurvitz et al. 2013; Krop et al. 2012; Yoon et al. 2011). Nevertheless, Yang et al. focus on tumorextrinsic resistance and propose a tumor-extrinsic strategy to bypass intrinsic $\mathrm{Ab}$ resistance by reactivating both innate and adaptive immune cells inside the tumor. Using Ab-sensitive TUBO (HER2/neu+) and Ab-resistant EGFR-transduced B16 mouse tumor models (Rovero et al. 2000), they found increased production of type I IFNs in the Ab-sensitive tumor model, in contrast to the Ab-resistant tumor model. These data suggest that enhanced type I IFN production was caused by Ab-induced oncogenic receptor and stress. Yang et al. are the first to point out that Type I IFNs are the cytokines essential for Ab-mediated tumor regression and tumor-targeting delivery of type I IFNs may induce stronger anti-tumor immune responses to overcome antibody resistance or tumor immune tolerance.

\section{Anti-CD20 antibody}

Rituximab is a murine-human chimeric antibody that recognizes the human B-cell CD20 antigen featuring primary response rates up to $70 \%$ (Maloney et al. 1992, 1994, 1997a, b). Similar to cetuximab and panitumumab, rituximab can induce tumor-cell death via ADCC, CDC, and apoptosis of tumor cells in vitro and in animal models (Clynes et al. 2000; Maloney 2012). Rituximab was approved by the FDA in 1997 for 
treating non-Hodgkin B-cell lymphoma. Effective control of B-cell lymphoma by anti-CD20 in xenograft models indicates the importance of direct tumor killing or innate-mediated killing induced by this antibody. However, the function of the adaptive immune response was later discovered to also play essential roles in lymphoma clearance. Using the huCD20-EL4 tumor model, a murine T-cell lymphoma transfected with the human CD20 molecule, Abes and Xuan reported that by the $\mathrm{CD} 4+$, but not CD8+, T-cell immune responses may contribute to long-lasting protection by anti-human CD20 treatment (Abes et al. 2010; Xuan et al. 2010). Conversely, Ren et al. reported in 2016 that CD8+ T cells alone, but not CD4+ T cells, contributed to the effective anti-mouse CD20 Ab therapy in a syngeneic A20 B-cell lymphoma mouse model. In this study, they characterized how anti-CD20 treatment initiated a potent tumorspecific T-cell response for tumor control. Ab could kill some tumor cells through ADCC by macrophages that produce type I IFNs for cross-priming; IFN binds to interferon $\alpha / \beta$ receptor (IFNAR) and activates Dendritic Cells (DCs) to better process tumor antigens for crosspriming T cells in the DLN; tumor-specific CTLs travel back to the tumor site for tumor control. They further demonstrated the role of CTLA-4 in Tregs within advanced B-cell lymphoma in limiting anti-CD20mediated tumor regression. Thus, anti-CTLA-4 and anti-CD20 combined treatment is a possible new clinical strategy in overcoming adaptive resistance and preventing relapse of B-cell lymphoma.

Overall, these studies reveal the essential contribution of adaptive immune responses in the early elimination and late resistance of TTmAb therapy. Most importantly, these studies have demonstrated that DCs are the major tolerized immune cells in tumors and DCs determine the immune-active or immunosuppressive status in TME. Targeting DCs will be another important strategy for improving the efficacy of cancer immunotherapy. This can be achieved by providing type I IFNs, the key players linking innate and adaptive antitumor immunity, to induce Ab-mediated tumor regression. Moreover, these studies raise the potential of using checkpoint blockades to overcome adaptive resistance in the future.

\section{ANTIBODY ARMED WITH CYTOKINES TO FURTHER PROMOTE ADAPTIVE ANTI-TUMOR IMMUNITY}

Type I IFNs, including IFN- $\alpha$, IFN- $\beta$, IFN- $\varepsilon$, IFN- $\kappa$, and IFN- $v$, are a family of monomeric cytokines with multiple functions (Pestka et al. 2004). Type I IFNs are involved in regulating many aspects of innate and adaptive immune responses by affecting the activation, migration, differentiation, and survival of macrophages, NK cells, DCs, monocytes, and B/T cells. Type I IFNs have been demonstrated to improve the antigen crosspresentation ability of CD8a+ DCs (Diamond et al. 2011; Lorenzi et al. 2011).

Due to their direct anti-proliferation and proapoptosis effects, Type I IFNs have been used for melanoma and lymphoma treatments. Recently, our laboratory and other research groups have found that endogenous type I IFNs perform significant functions in various antitumor therapies (Deng et al. 2014; Sistigu et al. 2014; Woo et al. 2014).

However, administration of type I IFNs has not been efficient in clinical cancer therapy, because of its limited potency and severe side effects (Trinchieri 2010). It has been suggested that the delivery of exogenous type I IFN may dramatically impact both immune responses and tumor cell proliferation/survival (Tang et al. 2016; Trinchieri 2010).

Yang et al. proposed that type I IFNs play an essential and sufficient role to bridge innate and adaptive antitumor immune responses during Ab-based antitumor therapy (Yang et al. 2014). They developed Ab-IFN $\beta$ as an advanced therapeutic strategy for those Ab-resistant tumors. Their study demonstrates that Ab-resistant tumors can be efficiently controlled by employing $\mathrm{Ab}-$ IFN $\beta$ fusion proteins. IFNAR on DCs, but not on tumor cells or $\mathrm{T}$ cells was required for the targeting effect of Ab-IFN $\beta$ which increases DC cross-presentation and antitumor CTL function.

Another study demonstrated that Anti-CD20-IFNa fusion protein was more effective than anti-CD20 Ab alone for direct killing of type IFN $\alpha$ receptor (IFNAR)positive lymphoma (Xuan et al. 2010). However, the function of IFNAR on host immune cells was not addressed. Using a syngeneic immunocompetent mouse model, Liao et al. observed that targeting lymphoma with IFN $\alpha$ abolished resistance of B-cell lymphoma to anti-CD20 Ab while also limiting interferon (IFN)-associated systemic toxicity in the host (Liao et al. 2017). Anti-CD20-IFN $\alpha$ fusion protein-mediated tumor control is dependent on existing tumor-infiltrating CD8+ T cells. Although resistant to direct killing induced by IFN $\alpha$, IFN-exposed A20 lymphoma cells become the dominant APCs for the reactivation of CTLs in the tumor. AntiCD20-IFN $\alpha$ also abolishes checkpoint blockade resistance in advanced B-cell lymphoma. Thus, this study indicates that anti-CD20-IFN $\alpha$ eradicates B-cell lymphoma by employing tumor cells as APCs to reactivate tumor-infiltrating CD8+ $\mathrm{T}$ cells and synergizing with anti-PD-L1 treatment. 
LIGHT ("the homologous to lymphotoxin that exhibits inducible expression and competes with HSV glycoprotein $\mathrm{D}$ for binding to herpesvirus entry mediator, a receptor expressed on T lymphocytes"), also known as tumor necrosis factor superfamily member 14 (TNFSF14), is one of the co-stimulatory molecules for T-cell activation (Lee et al. 2006; Wang et al. 2009). LIGHT is predominantly expressed on the surface of immature dendritic cells (DCs) and activated T cells. Several studies have indicated that LIGHT signaling might increase lymphocyte infiltration in the tumor (Yu et al. 2004, 2007; Zou et al. 2012). Based on LIGHT activities, Tang et al. constructed an anti-EGFR-LIGHT (Ab-LIGHT) targeting into EGFR+ but anti-PD-L1resistant tumor tissues (Tang et al. 2016). In the study, they demonstrated that LIGHT indeed induces lymphocyte infiltration and antitumor immunity in both mouse and human tumor model. They also proved that additional LIGHT treatment can promote the efficacy of checkpoint blockade therapies by enhancing lymphocyte infiltration. These data suggest that LIGHT could be used to increase the responsiveness to checkpoint blockades and other immunotherapies in non-T-cellinflamed tumors.

Interleukin-2 (IL-2) is a pleiotropic cytokine that promotes proliferation of $\mathrm{NK}$ and $\mathrm{T}$ cells induced by antigen stimulation (Liao et al. 2013; Morgan et al. 1976). IL-2 was one of the first FDA-approved immunotherapy drugs for metastatic melanoma and renal cell cancer (Rosenberg 2014; Rosenberg et al. 1998). However, IL-2 immunotherapy has not been widely employed because of its short half-life in vivo and severe toxicity at a therapeutic dose (Chavez et al. 2009; Panelli et al. 2004; Skrombolas and Frelinger 2014). In addition, IL-2 induces proliferation of regulatory T cells (Tregs) through binding to IL-2R alpha that is preferentially expressed on Tregs (Ahmadzadeh and Rosenberg 2006; Jensen et al. 2009; Sim et al. 2014), which might be a major barrier for IL-2-mediated expansion of CTL. To limit systemic toxicity, antibody-based delivery of IL-2 (Ab-IL2) has been investigated (Becker et al. 1996; Du et al. 2013; Gillies et al. 2011; Gutbrodt et al. 2013, 2014; Yang et al. 2013a). Systemic delivery of IL-2 may activate $\mathrm{T}$ cells in lymphoid and non-lymphoid tissues. The anti-tumor function of IL-2 therapy is known to directly activate CTLs (Gutbrodt et al. 2014; Jackaman et al. 2003). However, IL-2 induced Treg inhibitory effects are also significant. Thus, there are tremendous research efforts in constructing the mutant IL-2 with tumor targeting that increases binding to CD8+ T cells and reduces affinity to Tregs, which can alter antitumor response in tumor microenvironment and activate tumor-specific CTLs, thus leading to significantly improved anti-tumor responses (De Luca et al. 2017; Hartimath et al. 2018; Zhu et al. 2015). Similarly, IL-21, IL-12, and IL-15 cytokines are under investigation for possibilities in achieving potent tumortargeting effects with minor peripheral side effects.

In summary, these studies established new concepts for the Ab-based treatment, such as the Ab-IL2, AbIFN $\beta$, and Ab-LIGHT fusion proteins, which stimulate or augment the tumor-specific CTL responses to deal with $\mathrm{Ab}$ resistance and relapse more effectively. Killing more tumor cells by enhanced CTLs can then create a positive feedback loop for anti-tumor immune responses. In addition, all these studies conclude that blocking inhibitory PD-L1 upregulated by Ab-cytokine treatment may further improve the antitumor effect via recruiting more $\mathrm{Ab}$-cytokine molecules and open new avenues for future clinical cancer treatment.

\section{ANTIBODIES TARGETING TO IMMUNE INHIBITORY RECEPTORS AND COMBINATION THERAPIES}

\section{Anti-CD47}

CD47 is a major player of the 'donot eat me' signal (McCracken et al. 2015). The inhibitory phagocytic signaling is transduced when cell-surface CD47 binds signal-regulatory protein alpha (SIRP $\alpha$ ) on phagocytic cells (Willingham et al. 2012). CD47 is overexpressed on tumor cells and considered as a marker for cancer prognosis (Chan et al. 2009; Jaiswal et al. 2009; Majeti et al. 2009). The characteristic overexpression of CD47 on tumor cells also makes it a potential target for antibody-driven immunotherapy. There are several ongoing clinical trials for anti-CD47 monoclonal antibodies that have yet to yield conclusions (Russ et al. 2018). Risk for toxicity and anti-tumor effectiveness from a CD47 blockade is still under observation. Tumorassociated macrophages were commonly reported to be the major anti-tumor phagocytes in xenograft transplantation models, where the role of adaptive immunity is excluded (Chao et al 2010, 2011; Willingham et al. 2012). However, using syngeneic immune complete cancer mouse models instead of transplanted xenografts, Liu et al. first demonstrated that the anti-tumor effects mediated by the CD47 blockade was mostly dependent on the tumor-specific CD8+ T cells. CD11c + DCs, but not macrophages, are the major APCs for the cross-priming of CD8+ T cells in a STING signalingdependent manner to further drive type I IFN production and CTL activation. This DC activation was not induced by the MyD88 Toll-like receptor signaling as previously reported. The discovery of adaptive 
antitumor immunity mediated by CD47-targeting $\mathrm{Ab}$ blockade sheds light on designing new strategies with anti-CD47 in conjunction with traditional chemotherapeutics and other targeted therapies.

\section{Ab in combination with checkpoint blockade}

Cytotoxic T-lymphocyte-associated antigen-4 (CTLA4) and programmed death-1 (PD1) are two of the major co-inhibitory immune checkpoint molecules expressed on T cells. PD1 ligand (PDL1) is another immune inhibitory molecule expressed on dendritic cells, activated $\mathrm{T}$ cells, and tumor cells. Anti-CTLA4 and anti-PD1/PD-L1 monoclonal antibodies have been developed as checkpoint blockades to inhibit the suppressive function of CTLA4 or PD-1/PD-L1 (Pardoll 2012). Physiologically, these inhibitory molecules play important roles in protecting the host from autoimmune diseases (Keir et al. 2008; Nishimura et al. 2001). However, tumors take advantage of these pathways to escape antitumor immune responses (Dong et al. 2002; Iwai et al. 2002; Shin and Ribas, 2015). Nivolumab and pembrolizumab, two monoclonal antibodies targeting PD1, have shown impressive anti-tumor efficacy in melanoma and nonsmall cell lung cancer (NSCLC) (Brahmer et al. 2012; Robert et al. 2015a, b; Topalian et al. 2012). Ipilimumab, a first class anti-CTLA4 monoclonal antibody (Hodi et al. 2010; O'Day et al. 2007; Wolchok et al. 2010), is effective in about $10 \%-20 \%$ of patients (Maio et al. 2015; Schadendorf et al. 2015).

Studies have shown that checkpoint blockades can reverse T-cell suppression and improve the therapeutic effects. However, only a small number of patients are sensitive to such therapy. There is a pressing need for mechanism studies on this subject and potential mechanisms for synergistic effects. In the past 10 years, we and other laboratories have shown that anti-EGFR, anti-HER2, anti-CD20, and anti-CD47 in combination with immune checkpoint blockade could have synergistic effects in host adaptive anti-immune responses and tumor eradication. The mechanisms of such synergistic effect may be complicated. Antibodies targeting to tumor cells can not only reduce tumor burden but also change tumor microenvironment. Some antibodies, such as anti-Her2/neu, can increase IFN through MyD88, while others, such as anti-CD47, induce IFN through STING pathway. Our study also demonstrates that CTLA4 is a major immune suppressor in A20 tumors and leads to anti-CD20 resistance. Anti-CTLA- 4 and antiCD20 combined treatment overcomes adaptive resistance and prevents relapse in the mouse B-cell lymphoma model (Ren et al. 2017). But the mechanism is unclear. In another combination therapy, PD-L1 blockade could enhance the antitumor efficacy of antiCD20-IFN $\alpha$ and reduce relapse rates for advanced large tumors that are resistant to either anti-CD20 Ab or the anti-CD20-IFN $\alpha$ fusion protein (Liao et al. 2017). IFN can increase PD-L1 expression on tumor cells and antigen presentation, each of which represents distinct mechanism of tumor control. PD-L1 on tumor cells may prevent T-cell-mediated killing, while PD-L1 on antigenpresenting cells may suppress T-cell reactivation. The role of PD-L1 on draining LN is unclear.

In our most recent study, Tang et al. demonstrated that anti-PD-L1 is significantly accumulated in tumors after systemic treatment and could be utilized to deliver immunomodulatory molecules (Tang et al. 2018), such as IFN-anti-PD-L1, specifically into tumor tissues (unpublished data from Yang-Xin Fu's group). IFN-anti-PD-L1 may elicit a positive feedback loop to enhance targeting effects by upregulating PD-L1 expression, which is beneficial for treating tumors with lower levels of PD-L1. This strategy of PD-L1 antibody armed with IFN can overcome resistance to checkpoint blockade therapy in advanced tumors.

\section{Local radiotherapy can overcome PD-L1 resistance}

Radiotherapy (RT) is a cancer treatment that employs high dose of radiation to kill tumor cells and reduce tumor burden. Not only tumor cells but also stromal cells at the tumor site can be affected by radiation. Radiation-damaged cancer cells release tumor antigens, DNA and RNA that are captured by antigen-presenting cells to promote the priming and activation of cytotoxic $\mathrm{T}$ cells, and to facilitate further infiltration of immune cells. Radiation-induced inflammatory response may result in multiple IR-resistant signaling that facilitate tumor relapse (Barcellos-Hoff et al. 2005), including enhancement of PD-L1/PD-1. Thus, application of radiation therapy with TTmAb and checkpoint blockade may result in synergistic effects for cancer regression. Animal studies and clinical trials have been taken to explore the most effective combinations, which may depend on the tumor type, specific immunotherapy, and optimal timing. In a study of radiation therapy combined with checkpoint blockades, anti-CTLA4 functions most effectively when administrated ahead of radiation, but anti-OX40 must be given after radiation to improve treatment efficacy in a mouse tumor model (Young et al. 2016). Another study showed that PDL1 blockade could overcome radiotherapy resistance only when anti-PDL1 was given concurrently with radiation, not a week before or after radiation (Dovedi et al. 2014). 
Our previous study shows that upregulation of the PD-L1/PD-1 in tumor after IR inhibits radiation-induced anti-tumor immune responses and facilitates tumor relapse. Combination of IR with PD-L1 blockade results in the elimination of MDSCs by T-cell-derived TNF (Deng et al. 2014). This rational design of RT in combination with anti-PD-L1 should be referred to and applied in clinical cancer treatment. The optimization of radiation dose and timing is critical for enhancing the effectiveness of individual-based combination treatment.

\section{TTmAb combined with small molecule chemo- and targeted therapy}

Antibody treatment in combination with multiple chemo-therapeutic agents has been investigated in a number of tumor models (Pegram et al. 1999, 2004). There is no conclusive result for whether chemotherapy synergizes with anti-HER2/neu antibody (Hudis 2007; Piccart-Gebhart et al. 2005; Romond et al. 2005). Our previous studies have shown that the timing of chemotherapy administration is critical for synergistic effects when combined with anti-Her2 and anti-CD47 therapy (Liu et al. 2015; Park et al. 2010). Pretreatment with chemotherapy can enhance the anti-tumor effect of anti-Her2 and anti-CD47 therapy, whereas chemotherapy applied following anti-Her2 or anti-CD47 treatment abolishes the tumor regression induced by either single treatment and even destroyed the tumor-specific T-cell memory responses (Liu et al. 2015; Park et al. 2010).

Molecular targeted therapy functions through blocking the growth of cancer cells by interfering with tumorspecific targeted molecules needed for oncogenesis and tumor growth. Tyrosine kinase inhibitors that target EGFR family members are among the most successful targeted cancer therapies (Arteaga and Engelman 2014; Scaltriti and Baselga 2006; Wieduwilt and Moasser 2008). Although the standard HyperTKI (low dose with a high frequency) regimen has shown a promising initial anti-tumor effect, tumor relapse happens to almost all patients eventually within about 1 year. Besides improving response rates, significant reducing tumor relapse rates have been a big challenge for EGFR TKIs treatment.

Immunotherapy, such as nivolumab or pembrolizumab, has been approved as the standard secondline or third-line treatment for TKI-resistant patients with high-level PD-L1 expression in tumors. Unfortunately, recent clinical trials were prematurely terminated due to significant side effects from checkpoint blockade combined with prolonged treatment of EGFR TKIs, which has achieved higher response rates (Ahn et al. 2017). Therefore, safety and efficacy must be carefully evaluated for development of the combination of EGFR TKI and immunotherapy.

\section{SUMMARY AND PERSPECTIVES}

Recent work exploring the role of the tumor-targeting $\mathrm{Ab}$ in cancer therapy has yielded significant progress. Our laboratory's research and the work of other research groups show that tumor-targeting $\mathrm{Ab}$ can be effectively combined with traditional small molecule chemo- and targeted therapy as well as newly developed checkpoint blockades, thus providing new potential for creating highly specific therapies. By targeting tumors, these new therapies would address the fundamental mechanism behind tumor growth and metastasis, namely breaking immune tolerance. It is the TTmAb that bridges the innate and adaptive immunity to modulate tumor microenvironment, overcomes drug resistance, and induces effective anti-tumor response to achieve tumor regression. This is the underlying principle behind the ongoing interest in combining targeting $\mathrm{Ab}$ with radiation and small molecule chemo- and targeted therapies.

Although this review mainly focuses on the functional studies and the clinical application of tumor-targeting antibodies, recent evidence has shown further development of such antibody fusion proteins armed with inflammation cytokines, including IFN, LIGHT, and IL-2. Moreover, immune checkpoints have been deemed critical for the cancer immune tolerance. As such, tumor-targeting checkpoint blockade would be a worthy direction for extensive future study. Exploring the synergistic treatment effect between targeting antibodies, immune cytokines, checkpoint blockade, radiotherapy, and small molecule chemo- and targeted therapies holds great promise for elucidating the underlying immunology mechanisms as well as developing effective therapies for a broad range of malignant diseases.

\section{Compliance with ethical standards}

Conflict of interest Hua Peng, Zhichen Sun, and Yang-Xin Fu declare that they have no conflict of interest.

Human and animal rights and informed consent This article does not contain any studies with human or animal subjects performed by the any of the authors.

Open Access This article is distributed under the terms of the Creative Commons Attribution 4.0 International License (http:// creativecommons.org/licenses/by/4.0/), which permits unrestricted use, distribution, and reproduction in any medium, provided you give appropriate credit to the original author(s) and the source, provide a link to the Creative Commons license, and indicate if changes were made. 


\section{References}

Abes R, Gelize E, Fridman WH, Teillaud JL (2010) Long-lasting antitumor protection by anti-CD20 antibody through cellular immune response. Blood 116:926-934

Abramson V, Arteaga CL (2011) New strategies in HER2overexpressing breast cancer: many combinations of targeted drugs available. Clin Cancer Res 17:952-958

Ahmadzadeh M, Rosenberg SA (2006) IL-2 administration increases CD4+ CD25(hi) Foxp3+ regulatory T cells in cancer patients. Blood 107:2409-2414

Ahn MJ, Sun JM, Lee SH, Ahn JS, Park K (2017) EGFR TKI combination with immunotherapy in non-small cell lung cancer. Expert Opin Drug Saf 16:465-469

Arteaga CL, Engelman JA (2014) ERBB receptors: from oncogene discovery to basic science to mechanism-based cancer therapeutics. Cancer Cell 25:282-303

Barcellos-Hoff MH, Park C, Wright EG (2005) Radiation and the microenvironment-tumorigenesis and therapy. Nat Rev Cancer 5:867-875

Bardelli A, Siena S (2010) Molecular mechanisms of resistance to cetuximab and panitumumab in colorectal cancer. J Clin Oncol 28:1254-1261

Becker JC, Varki N, Gillies SD, Furukawa K, Reisfeld RA (1996) An antibody-interleukin 2 fusion protein overcomes tumor heterogeneity by induction of a cellular immune response. Proc Natl Acad Sci USA 93:7826-7831

Bostrom J, Yu SF, Kan D, Appleton BA, Lee CV, Billeci K, Man W, Peale F, Ross S, Wiesmann C, Fuh G (2009) Variants of the antibody herceptin that interact with HER2 and VEGF at the antigen binding site. Science 323:1610-1614

Brahmer JR, Tykodi SS, Chow LQ Hwu WJ, Topalian SL, Hwu P, Drake CG, Camacho LH, Kauh J, Odunsi K, Pitot HC, Hamid O, Bhatia S, Martins R, Eaton K, Chen S, Salay TM, Alaparthy S, Grosso JF, Korman AJ, Parker SM, Agrawal S, Goldberg SM, Pardoll DM, Gupta A, Wigginton JM (2012) Safety and activity of anti-PD-L1 antibody in patients with advanced cancer. N Engl J Med 366:2455-2465

Burgess AW, Cho HS, Eigenbrot C, Ferguson KM, Garrett TP, Leahy DJ, Lemmon MA, Sliwkowski MX, Ward CW, Yokoyama S (2003) An open-and-shut case? Recent insights into the activation of EGF/ErbB receptors. Mol Cell 12:541-552

Carter P, Presta L, Gorman CM, Ridgway JB, Henner D, Wong WL, Rowland AM, Kotts C, Carver ME, Shepard HM (1992) Humanization of an anti-p185HER2 antibody for human cancer therapy. Proc Natl Acad Sci USA 89:4285-4289

Chan KS, Espinosa I, Chao M, Wong D, Ailles L, Diehn M, Gill H, Presti J Jr, Chang HY, van de Rijn M, Shortliffe L, Weissman IL (2009) Identification, molecular characterization, clinical prognosis, and therapeutic targeting of human bladder tumor-initiating cells. Proc Natl Acad Sci USA 106:14016-14021

Chao MP, Alizadeh AA, Tang C, Myklebust JH, Varghese B, Gill S, Jan M, Cha AC, Chan CK, Tan BT, Park CY, Zhao F, Kohrt HE, Malumbres R, Briones J, Gascoyne RD, Lossos IS, Levy R, Weissman IL, Majeti R (2010) Anti-CD47 antibody synergizes with rituximab to promote phagocytosis and eradicate nonHodgkin lymphoma. Cell 142:699-713

Chao MP, Alizadeh AA, Tang C, Jan M, Weissman-Tsukamoto R, Zhao F, Park CY, Weissman IL, Majeti R (2011) Therapeutic antibody targeting of CD47 eliminates human acute lymphoblastic leukemia. Cancer Res 71:1374-1384

Chavez AR, Buchser W, Basse PH, Liang X, Appleman LJ, Maranchie JK, Zeh H, de Vera ME, Lotze MT (2009) Pharmacologic administration of interleukin-2. Ann N Y Acad Sci 1182:14-27
Citri A, Yarden Y (2006) EGF-ERBB signalling: towards the systems level. Nat Rev Mol Cell Biol 7:505-516

Clynes RA, Towers TL, Presta LG, Ravetch JV (2000) Inhibitory Fc receptors modulate in vivo cytotoxicity against tumor targets. Nat Med 6:443-446

Cobleigh MA, Vogel CL, Tripathy D, Robert NJ, Scholl S, Fehrenbacher L, Wolter JM, Paton V, Shak S, Lieberman G, Slamon DJ (1999) Multinational study of the efficacy and safety of humanized anti-HER2 monoclonal antibody in women who have HER2-overexpressing metastatic breast cancer that has progressed after chemotherapy for metastatic disease. J Clin Oncol 17:2639-2648

De Luca R, Soltermann A, Pretto F, Pemberton-Ross C, Pellegrini G, Wulhfard S, Neri D (2017) Potency-matched dual cytokineantibody fusion proteins for cancer therapy. Mol Cancer Ther 16:2442-2451

Deng L, Liang H, Xu M, Yang X, Burnette B, Arina A, Li XD, Mauceri H, Beckett M, Darga T, Huang X, Gajewski TF, Chen ZJ, Fu YX, Weichselbaum RR (2014) STING-dependent cytosolic dna sensing promotes radiation-induced type I interferondependent antitumor immunity in immunogenic tumors. Immunity 41:843-852

Diamond MS, Kinder M, Matsushita H, Mashayekhi M, Dunn GP, Archambault JM, Lee H, Arthur CD, White JM, Kalinke U, Murphy KM, Schreiber RD (2011) Type I interferon is selectively required by dendritic cells for immune rejection of tumors. J Exp Med 208:1989-2003

Dong H, Strome SE, Salomao DR, Tamura H, Hirano F, Flies DB, Roche PC, Lu J, Zhu G, Tamada K, Lennon VA, Celis E, Chen L (2002) Tumor-associated B7-H1 promotes T-cell apoptosis: a potential mechanism of immune evasion. Nat Med 8:793-800

Dovedi SJ, Adlard AL, Lipowska-Bhalla G, McKenna C, Jones S, Cheadle EJ, Stratford IJ, Poon E, Morrow M, Stewart R, Jones H, Wilkinson RW, Honeychurch J, Illidge TM (2014) Acquired resistance to fractionated radiotherapy can be overcome by concurrent PD-L1 blockade. Cancer Res 74:5458-5468

Du YJ, Lin ZM, Zhao YH, Feng XP, Wang CQ, Wang G, Wang CD, Shi W, Zuo JP, Li F, Wang CZ (2013) Stability of the recombinant anti-erbB2 scFv-Fc-interleukin-2 fusion protein and its inhibition of HER2-overexpressing tumor cells. Int J Oncol 42:507-516

Ennis BW, Lippman ME, Dickson RB (1991) The EGF receptor system as a target for antitumor therapy. Cancer Invest 9:553-562

Fayad L, Offner F, Smith MR, Verhoef G, Johnson P, Kaufman JL, Rohatiner A, Advani A, Foran J, Hess G, Coiffier B, Czuczman M, Gine E, Durrant S, Kneissl M, Luu KT, Hua SY, Boni J, Vandendries E, Dang NH (2013) Safety and clinical activity of a combination therapy comprising two antibody-based targeting agents for the treatment of non-Hodgkin lymphoma: results of a phase I/II study evaluating the immunoconjugate inotuzumab ozogamicin with rituximab. J Clin Oncol 31:573-583

Gillies SD, Lan Y, Hettmann T, Brunkhorst B, Sun Y, Mueller SO, Lo KM (2011) A low-toxicity IL-2-based immunocytokine retains antitumor activity despite its high degree of IL-2 receptor selectivity. Clin Cancer Res 17:3673-3685

Gutbrodt KL, Schliemann C, Giovannoni L, Frey K, Pabst T, Klapper W, Berdel WE, Neri D (2013) Antibody-based delivery of interleukin-2 to neovasculature has potent activity against acute myeloid leukemia. Sci Transl Med 5:201ra118

Gutbrodt KL, Casi G, Neri D (2014) Antibody-based delivery of IL2 and cytotoxics eradicates tumors in immunocompetent mice. Mol Cancer Ther 13:1772-1776

Hartimath SV, Manuelli V, Zijlma R, Signore A, Nayak TK, Freimoser-Grundschober A, Klein C, Dierckx R, de Vries EFJ 
(2018) Pharmacokinetic properties of radiolabeled mutant Interleukin-2v: a PET imaging study. Oncotarget 9:7162-7174

Hodi FS, O'Day SJ, McDermott DF, Weber RW, Sosman JA, Haanen JB, Gonzalez R, Robert C, Schadendorf D, Hassel JC, Akerley W, van den Eertwegh AJ, Lutzky J, Lorigan P, Vaubel JM, Linette GP, Hogg D, Ottensmeier CH, Lebbe C, Peschel C, Quirt I, Clark JI, Wolchok JD, Weber JS, Tian J, Yellin MJ, Nichol GM, Hoos A, Urba WJ (2010) Improved survival with ipilimumab in patients with metastatic melanoma. $N$ Engl J Med 363:711-723

Hudis CA (2007) Trastuzumab-mechanism of action and use in clinical practice. N Engl J Med 357:39-51

Hurvitz SA, Dirix L, Kocsis J, Bianchi GV, Lu J, Vinholes J, Guardino E, Song C, Tong B, Ng V, Chu YW, Perez EA (2013) Phase II randomized study of trastuzumab emtansine versus trastuzumab plus docetaxel in patients with human epidermal growth factor receptor 2-positive metastatic breast cancer. J Clin Oncol 31:1157-1163

Hynes NE, Lane HA (2005) ERBB receptors and cancer: the complexity of targeted inhibitors. Nat Rev Cancer 5:341-354

Iwai Y, Ishida M, Tanaka Y, Okazaki T, Honjo T, Minato N (2002) Involvement of PD-L1 on tumor cells in the escape from host immune system and tumor immunotherapy by PD-L1 blockade. Proc Natl Acad Sci USA 99:12293-12297

Jackaman C, Bundell CS, Kinnear BF, Smith AM, Filion P, van Hagen D, Robinson BWS, Nelson DJ (2003) IL-2 intratumoral immunotherapy enhances CD8+ T cells that mediate destruction of tumor cells and tumor-associated vasculature: a novel mechanism for IL-2. J Immunol 171:5051-5063

Jaiswal S, Jamieson CH, Pang WW, Park CY, Chao MP, Majeti R, Traver D, van Rooijen N, Weissman IL (2009) CD47 is upregulated on circulating hematopoietic stem cells and leukemia cells to avoid phagocytosis. Cell 138:271-285

Jensen HK, Donskov F, Nordsmark M, Marcussen N, von der Maase H (2009) Increased intratumoral FOXP3-positive regulatory immune cells during interleukin-2 treatment in metastatic renal cell carcinoma. Clin Cancer Res 15:1052-1058

Keir ME, Butte MJ, Freeman GJ, Sharpe AH (2008) PD-1 and its ligands in tolerance and immunity. Annu Rev Immunol 26:677-704

Kiessling R, Wei WZ, Herrmann F, Lindencrona JA, Choudhury A, Kono K, Seliger B (2002) Cellular immunity to the Her-2/neu protooncogene. Adv Cancer Res 85:101-144

Kimura H, Sakai K, Arao T, Shimoyama T, Tamura T, Nishio K (2007) Antibody-dependent cellular cytotoxicity of cetuximab against tumor cells with wild-type or mutant epidermal growth factor receptor. Cancer Sci 98:1275-1280

Krop IE, LoRusso P, Miller KD, Modi S, Yardley D, Rodriguez G, Guardino E, Lu M, Zheng M, Girish S, Amler L, Winer EP, Rugo HS (2012) A phase II study of trastuzumab emtansine in patients with human epidermal growth factor receptor 2-positive metastatic breast cancer who were previously treated with trastuzumab, lapatinib, an anthracycline, a taxane, and capecitabine. J Clin Oncol 30:3234-3241

Le XF, Lammayot A, Gold D, Lu Y, Mao W, Chang T, Patel A, Mills GB, Bast RC Jr (2005) Genes affecting the cell cycle, growth, maintenance, and drug sensitivity are preferentially regulated by anti-HER2 antibody through phosphatidylinositol 3-kinase-AKT signaling. J Biol Chem 280:2092-2104

Lee Y, Chin RK, Christiansen P, Sun Y, Tumanov AV, Wang J, Chervonsky AV, Fu YX (2006) Recruitment and activation of naive $\mathrm{T}$ cells in the islets by lymphotoxin beta receptordependent tertiary lymphoid structure. Immunity 25:499-509
Li S, Schmitz KR, Jeffrey PD, Wiltzius JJ, Kussie P, Ferguson KM (2005) Structural basis for inhibition of the epidermal growth factor receptor by cetuximab. Cancer Cell 7:301-311

Liao W, Lin JX, Leonard WJ (2013) Interleukin-2 at the crossroads of effector responses, tolerance, and immunotherapy. Immunity 38:13-25

Liao J, Luan Y, Ren Z, Liu X, Xue D, Xu H, Sun Z, Yang K, Peng H, Fu YX (2017) Converting lymphoma cells into potent antigenpresenting cells for interferon-induced tumor regression. Cancer Immunol Res 5:560-570

Liu X, Pu Y, Cron K, Deng L, Kline J, Frazier WA, Xu H, Peng H, Fu YX, Xu MM (2015) CD47 blockade triggers T cell-mediated destruction of immunogenic tumors. Nat Med 21:1209-1215

Lorenzi S, Mattei F, Sistigu A, Bracci L, Spadaro F, Sanchez M, Spada M, Belardelli F, Gabriele L, Schiavoni G (2011) Type I IFNs control antigen retention and survival of CD8alpha(+) dendritic cells after uptake of tumor apoptotic cells leading to cross-priming. J Immunol 186:5142-5150

Maio M, Grob JJ, Aamdal S, Bondarenko I, Robert C, Thomas L, Garbe C, Chiarion-Sileni V, Testori A, Chen TT, Tschaika M, Wolchok JD (2015) Five-year survival rates for treatmentnaive patients with advanced melanoma who received ipilimumab plus dacarbazine in a phase III trial. J Clin Oncol 33:1191-1196

Majeti R, Chao MP, Alizadeh AA, Pang WW, Jaiswal S, Gibbs KD Jr, van Rooijen N, Weissman IL (2009) CD47 is an adverse prognostic factor and therapeutic antibody target on human acute myeloid leukemia stem cells. Cell 138:286-299

Maloney DG (2012) Anti-CD20 antibody therapy for B-cell lymphomas. N Engl J Med 366:2008-2016

Maloney DG, Brown S, Czerwinski DK, Liles TM, Hart SM, Miller RA, Levy R (1992) Monoclonal anti-idiotype antibody therapy of B-cell lymphoma: the addition of a short course of chemotherapy does not interfere with the antitumor effect nor prevent the emergence of idiotype-negative variant cells. Blood 80:1502-1510

Maloney DG, Liles TM, Czerwinski DK, Waldichuk C, Rosenberg J, Grillo-Lopez A, Levy R (1994) Phase I clinical trial using escalating single-dose infusion of chimeric anti-CD20 monoclonal antibody (IDEC-C2B8) in patients with recurrent B-cell lymphoma. Blood 84:2457-2466

Maloney DG, Grillo-Lopez AJ, Bodkin DJ, White CA, Liles TM, Royston I, Varns C, Rosenberg J, Levy R (1997a) IDEC-C2B8: results of a phase I multiple-dose trial in patients with relapsed non-Hodgkin's lymphoma. J Clin Oncol 15:3266-3274

Maloney DG, Grillo-Lopez AJ, White CA, Bodkin D, Schilder RJ, Neidhart JA, Janakiraman N, Foon KA, Liles TM, Dallaire BK, Wey K, Royston I, Davis T, Levy R (1997b) IDEC-C2B8 (Rituximab) anti-CD20 monoclonal antibody therapy in patients with relapsed low-grade non-Hodgkin's lymphoma. Blood 90:2188-2195

McCracken MN, Cha AC, Weissman IL (2015) Molecular pathways: activating $\mathrm{T}$ cells after cancer cell phagocytosis from blockade of CD47 "Don't Eat Me" signals. Clin Cancer Res 21:3597-3601

Menard S, Pupa SM, Campiglio M, Tagliabue E (2003) Biologic and therapeutic role of HER2 in cancer. Oncogene 22:6570-6578

Meric-Bernstam F, Hung MC (2006) Advances in targeting human epidermal growth factor receptor-2 signaling for cancer therapy. Clin Cancer Res 12:6326-6330

Misale S, Yaeger R, Hobor S, Scala E, Janakiraman M, Liska D, Valtorta E, Schiavo R, Buscarino M, Siravegna G, Bencardino K, Cercek A, Chen CT, Veronese S, Zanon C, Sartore-Bianchi A Gambacorta M, Gallicchio M, Vakiani E, Boscaro V, Medico E, Weiser M, Siena S, Di Nicolantonio F, Solit D, Bardelli A (2012) 
Emergence of KRAS mutations and acquired resistance to anti-EGFR therapy in colorectal cancer. Nature 486:532-536

Mittendorf EA, Liu Y, Tucker SL, McKenzie T, Qiao N, Akli S, Biernacka A, Liu Y, Meijer L, Keyomarsi K, Hunt KK (2010) A novel interaction between HER2/neu and cyclin E in breast cancer. Oncogene 29:3896-3907

Moasser MM (2007) Targeting the function of the HER2 oncogene in human cancer therapeutics. Oncogene 26:6577-6592

Morgan DA, Ruscetti FW, Gallo R (1976) Selective in vitro growth of T lymphocytes from normal human bone marrows. Science 193:1007-1008

Mortenson ED, Park S, Jiang Z, Wang S, Fu YX (2013) Effective anti-neu-initiated antitumor responses require the complex role of CD4+ T cells. Clin Cancer Res 19:1476-1486

Musolino A, Naldi N, Bortesi B, Pezzuolo D, Capelletti M, Missale G, Laccabue D, Zerbini A, Camisa R, Bisagni G, Neri TM, Ardizzoni A (2008) Immunoglobulin $G$ fragment $C$ receptor polymorphisms and clinical efficacy of trastuzumab-based therapy in patients with HER-2/neu-positive metastatic breast cancer. J Clin Oncol 26:1789-1796

Nahta R, Esteva FJ (2006) Herceptin: mechanisms of action and resistance. Cancer Lett 232:123-138

Nishimura H, Okazaki T, Tanaka Y, Nakatani K, Hara M, Matsumori A, Sasayama S, Mizoguchi A, Hiai H, Minato N, Honjo T (2001) Autoimmune dilated cardiomyopathy in PD-1 receptordeficient mice. Science 291:319-322

O'Day SJ, Hamid O, Urba WJ (2007) Targeting cytotoxic T-lymphocyte antigen-4 (CTLA-4): a novel strategy for the treatment of melanoma and other malignancies. Cancer 110:2614-2627

Olayioye MA, Neve RM, Lane HA, Hynes NE (2000) The ErbB signaling network: receptor heterodimerization in development and cancer. EMBO J 19:3159-3167

Panelli MC, White R, Foster M, Martin B, Wang E, Smith K, Marincola FM (2004) Forecasting the cytokine storm following systemic interleukin (IL)-2 administration. J Transl Med 2:17

Pardoll DM (2012) The blockade of immune checkpoints in cancer immunotherapy. Nat Rev Cancer 12:252-264

Park S, Jiang Z, Mortenson ED, Deng L, Radkevich-Brown O, Yang X, Sattar H, Wang Y, Brown NK, Greene M, Liu Y, Tang J, Wang S, $\mathrm{Fu}$ YX (2010) The therapeutic effect of anti-HER2/neu antibody depends on both innate and adaptive immunity. Cancer Cell 18:160-170

Pegram M, Hsu S, Lewis G, Pietras R, Beryt M, Sliwkowski M, Coombs D, Baly D, Kabbinavar F, Slamon D (1999) Inhibitory effects of combinations of HER-2/neu antibody and chemotherapeutic agents used for treatment of human breast cancers. Oncogene 18:2241-2251

Pegram MD, Konecny GE, O'Callaghan C, Beryt M, Pietras R, Slamon DJ (2004) Rational combinations of trastuzumab with chemotherapeutic drugs used in the treatment of breast cancer. J Natl Cancer Inst 96:739-749

Pestka S, Krause CD, Walter MR (2004) Interferons, interferon-like cytokines, and their receptors. Immunol Rev 202:8-32

Piccart-Gebhart MJ, Procter M, Leyland-Jones B, Goldhirsch A, Untch M, Smith I, Gianni L, Baselga J, Bell R, Jackisch C, Cameron D, Dowsett M, Barrios $\mathrm{CH}$, Steger G, Huang CS, Andersson M, Inbar M, Lichinitser M, Lang I, Nitz U, Iwata $\mathrm{H}$, Thomssen C, Lohrisch C, Suter TM, Ruschoff J, Suto T, Greatorex V, Ward C, Straehle C, McFadden E, Dolci MS, Gelber RD (2005) Trastuzumab after adjuvant chemotherapy in HER2-positive breast cancer. N Engl J Med 353:1659-1672

Quaglino E, Mastini C, Forni G, Cavallo F (2008) ErbB2 transgenic mice: a tool for investigation of the immune prevention and treatment of mammary carcinomas. Curr Protoc Immunol 82(1):20-29

Rajkumar T, Gullick WJ (1994) The type I growth factor receptors in human breast cancer. Breast Cancer Res Treat 29:3-9

Ren Z, Guo J, Liao J, Luan Y, Liu Z, Sun Z, Liu X, Liang Y, Peng H, Fu YX (2017) CTLA-4 limits anti-CD20-mediated tumor regression. Clin Cancer Res 23:193-203

Robert C, Long GV, Brady B, Dutriaux C, Maio M, Mortier L, Hassel JC, Rutkowski P, McNeil C, Kalinka-Warzocha E, Savage KJ, Hernberg MM, Lebbe C, Charles J, Mihalcioiu C, ChiarionSileni V, Mauch C, Cognetti F, Arance A, Schmidt H, Schadendorf D, Gogas H, Lundgren-Eriksson L, Horak C, Sharkey B, Waxman IM, Atkinson V, Ascierto PA (2015a) Nivolumab in previously untreated melanoma without BRAF mutation. N Engl J Med 372:320-330

Robert C, Schachter J, Long GV, Arance A, Grob JJ, Mortier L, Daud A, Carlino MS, McNeil C, Lotem M, Larkin J, Lorigan P, Neyns B, Blank CU, Hamid O, Mateus C, Shapira-Frommer R, Kosh M, Zhou H, Ibrahim N, Ebbinghaus S, Ribas A (2015b) Pembrolizumab versus ipilimumab in advanced melanoma. N Engl J Med 372:2521-2532

Romond EH, Perez EA, Bryant J, Suman VJ, Geyer CE Jr, Davidson NE, Tan-Chiu E, Martino S, Paik S, Kaufman PA, Swain SM, Pisansky TM, Fehrenbacher L, Kutteh LA, Vogel VG, Visscher DW, Yothers G, Jenkins RB, Brown AM, Dakhil SR, Mamounas EP, Lingle WL, Klein PM, Ingle JN, Wolmark N (2005) Trastuzumab plus adjuvant chemotherapy for operable HER2-positive breast cancer. N Engl J Med 353:1673-1684

Rosenberg SA (2014) IL-2: the first effective immunotherapy for human cancer. J Immunol 192:5451-5458

Rosenberg SA, Yang JC, White DE, Steinberg SM (1998) Durability of complete responses in patients with metastatic cancer treated with high-dose interleukin-2: identification of the antigens mediating response. Ann Surg 228:307-319

Rovero S, Amici A, Di Carlo E, Bei R, Nanni P, Quaglino E, Porcedda P, Boggio K, Smorlesi A, Lollini PL, Landuzzi L, Colombo MP, Giovarelli M, Musiani P, Forni G (2000) DNA vaccination against rat her-2/Neu p185 more effectively inhibits carcinogenesis than transplantable carcinomas in transgenic BALB/c mice. J Immunol 165:5133-5142

Russ A, Hua AB, Montfort WR, Rahman B, Riaz IB, Khalid MU, Carew JS, Nawrocki ST, Persky D, Anwer F (2018) Blocking "don't eat me" signal of CD47-SIRPalpha in hematological malignancies, an in-depth review. Blood Rev. https://doi.org/ 10.1016/j.blre.2018.04.005

Scaltriti M, Baselga J (2006) The epidermal growth factor receptor pathway: a model for targeted therapy. Clin Cancer Res 12:5268-5272

Schadendorf D, Hodi FS, Robert C, Weber JS, Margolin K, Hamid O, Patt D, Chen TT, Berman DM, Wolchok JD (2015) Pooled analysis of long-term survival data from phase II and phase III trials of ipilimumab in unresectable or metastatic melanoma. J Clin Oncol 33:1889-1894

Shepard HM, Brdlik CM, Schreiber H (2008) Signal integration: a framework for understanding the efficacy of therapeutics targeting the human EGFR family. J Clin Investig 118:3574-3581

Shin DS, Ribas A (2015) The evolution of checkpoint blockade as a cancer therapy: what's here, what's next? Curr Opin Immunol 33:23-35

Sim GC, Martin-Orozco N, Jin L, Yang Y, Wu S, Washington E, Sanders D, Lacey C, Wang Y, Vence L, Hwu P, Radvanyi L (2014) IL-2 therapy promotes suppressive ICOS+ Treg expansion in melanoma patients. J Clin Investig 124:99-110

Sistigu A, Yamazaki T, Vacchelli E, Chaba K, Enot DP, Adam J, Vitale I, Goubar A, Baracco EE, Remedios C, Fend L, Hannani D, 
Aymeric L, Ma Y, Niso-Santano M, Kepp O, Schultze JL, Tuting T, Belardelli F, Bracci L, La Sorsa V, Ziccheddu G, Sestili P, Urbani F, Delorenzi M, Lacroix-Triki M, Quidville V, Conforti R, Spano JP, Pusztai L, Poirier-Colame V, Delaloge S, PenaultLlorca F, Ladoire S, Arnould L, Cyrta J, Dessoliers MC, Eggermont A, Bianchi ME, Pittet M, Engblom C, Pfirschke C, Preville X, Uze G, Schreiber RD, Chow MT, Smyth MJ, Proietti E, Andre F, Kroemer G, Zitvogel L (2014) Cancer cellautonomous contribution of type I interferon signaling to the efficacy of chemotherapy. Nat Med 20:1301-1309

Skrombolas D, Frelinger JG (2014) Challenges and developing solutions for increasing the benefits of IL-2 treatment in tumor therapy. Expert Rev Clin Immunol 10:207-217

Slamon DJ, Clark GM, Wong SG, Levin WJ, Ullrich A, McGuire WL (1987) Human breast cancer: correlation of relapse and survival with amplification of the HER-2/neu oncogene. Science 235:177-182

Stagg J, Loi S, Divisekera U, Ngiow SF, Duret H, Yagita H, Teng MW, Smyth MJ (2011) Anti-ErbB-2 mAb therapy requires type I and II interferons and synergizes with anti-PD-1 or antiCD137 mAb therapy. Proc Natl Acad Sci USA 108:7142-7147

Sunada H, Magun BE, Mendelsohn J, MacLeod CL (1986) Monoclonal antibody against epidermal growth factor receptor is internalized without stimulating receptor phosphorylation. Proc Natl Acad Sci USA 83:3825-3829

Tang H, Wang Y, Chlewicki LK, Zhang Y, Guo J, Liang W, Wang J, Wang X, Fu YX (2016) Facilitating T cell infiltration in tumor microenvironment overcomes resistance to PD-L1 blockade. Cancer Cell 30:500

Tang H, Liang Y, Anders RA, Taube JM, Qiu X, Mulgaonkar A, Liu X, Harrington SM, Guo J, Xin Y, Xiong Y, Nham K, Silvers W, Hao G, Sun X, Chen M, Hannan R, Qiao J, Dong H, Peng H, Fu YX (2018) PD-L1 on host cells is essential for PD-L1 blockademediated tumor regression. J Clin Investig 128:580-588

Teeling JL, French RR, Cragg MS, van den Brakel J, Pluyter M, Huang H, Chan C, Parren PW, Hack CE, Dechant M, Valerius T, van de Winkel JG, Glennie MJ (2004) Characterization of new human CD20 monoclonal antibodies with potent cytolytic activity against non-Hodgkin lymphomas. Blood 104:1793-1800

Topalian SL, Hodi FS, Brahmer JR, Gettinger SN, Smith DC, McDermott DF, Powderly JD, Carvajal RD, Sosman JA, Atkins MB, Leming PD, Spigel DR, Antonia SJ, Horn L, Drake CG, Pardoll DM, Chen L, Sharfman WH, Anders RA, Taube JM, McMiller TL, Xu H, Korman AJ, Jure-Kunkel M, Agrawal S, McDonald D, Kollia GD, Gupta A, Wigginton JM, Sznol M (2012) Safety, activity, and immune correlates of anti-PD-1 antibody in cancer. N Engl J Med 366:2443-2454

Trinchieri G (2010) Type I interferon: friend or foe? J Exp Med 207:2053-2063

van Meerten T, van Rijn RS, Hol S, Hagenbeek A, Ebeling SB (2006) Complement-induced cell death by rituximab depends on CD20 expression level and acts complementary to antibodydependent cellular cytotoxicity. Clin Cancer Res 12:4027-4035

Wang Y, Zhu M, Miller M, Fu YX (2009) Immunoregulation by tumor necrosis factor superfamily member LIGHT. Immunol Rev 229:232-243

Wieduwilt MJ, Moasser MM (2008) The epidermal growth factor receptor family: biology driving targeted therapeutics. Cell Mol Life Sci 65:1566-1584

Willingham SB, Volkmer JP, Gentles AJ, Sahoo D, Dalerba P, Mitra SS, Wang J, Contreras-Trujillo H, Martin R, Cohen JD, Lovelace P, Scheeren FA, Chao MP, Weiskopf K, Tang C, Volkmer AK, Naik TJ, Storm TA, Mosley AR, Edris B, Schmid SM, Sun CK, Chua MS, Murillo O, Rajendran P, Cha AC, Chin RK, Kim D,
Adorno M, Raveh T, Tseng D, Jaiswal S, Enger PO, Steinberg GK, Li G, So SK, Majeti R, Harsh GR, van de Rijn M, Teng NN, Sunwoo JB, Alizadeh AA, Clarke MF, Weissman IL (2012) The CD47-signal regulatory protein alpha (SIRPa) interaction is a therapeutic target for human solid tumors. Proc Natl Acad Sci USA 109:6662-6667

Wolchok JD, Neyns B, Linette G, Negrier S, Lutzky J, Thomas L, Waterfield W, Schadendorf D, Smylie M, Guthrie T Jr, Grob JJ, Chesney J, Chin K, Chen K, Hoos A, O’Day SJ, Lebbe C (2010) Ipilimumab monotherapy in patients with pretreated advanced melanoma: a randomised, double-blind, multicentre, phase 2, dose-ranging study. Lancet Oncol 11:155-164

Woo SR, Fuertes MB, Corrales L, Spranger S, Furdyna MJ, Leung MY, Duggan R, Wang Y, Barber GN, Fitzgerald KA, Alegre ML, Gajewski TF (2014) STING-dependent cytosolic DNA sensing mediates innate immune recognition of immunogenic tumors. Immunity 41:830-842

Xuan C, Steward KK, Timmerman JM, Morrison SL (2010) Targeted delivery of interferon-alpha via fusion to anti-CD20 results in potent antitumor activity against B-cell lymphoma. Blood 115:2864-2871

Yang XD, Jia XC, Corvalan JR, Wang P, Davis CG (2001) Development of ABX-EGF, a fully human anti-EGF receptor monoclonal antibody, for cancer therapy. Crit Rev Oncol Hematol 38:17-23

Yang RK, Kalogriopoulos NA, Rakhmilevich AL, Ranheim EA, Seo S, Kim K, Alderson KL, Gan J, Reisfeld RA, Gillies SD, Hank JA, Sondel PM (2013a) Intratumoral treatment of smaller mouse neuroblastoma tumors with a recombinant protein consisting of IL-2 linked to the hu14.18 antibody increases intratumoral CD8+ T and NK cells and improves survival. Cancer Immunol Immunother 62:1303-1313

Yang X, Zhang X, Mortenson ED, Radkevich-Brown O, Wang Y, Fu YX (2013b) Cetuximab-mediated tumor regression depends on innate and adaptive immune responses. Mol Ther 21:91-100

Yang X, Zhang X, Fu ML, Weichselbaum RR, Gajewski TF, Guo Y, Fu YX (2014) Targeting the tumor microenvironment with interferon-beta bridges innate and adaptive immune responses. Cancer Cell 25:37-48

Yarden Y, Pines G (2012) The ERBB network: at last, cancer therapy meets systems biology. Nat Rev Cancer 12:553-563

Yarden Y, Sliwkowski MX (2001) Untangling the ErbB signalling network. Nat Rev Mol Cell Biol 2:127-137

Yonesaka K, Zejnullahu K, Okamoto I, Satoh T, Cappuzzo F, Souglakos J, Ercan D, Rogers A, Roncalli M, Takeda M, Fujisaka Y, Philips J, Shimizu T, Maenishi O, Cho Y, Sun J, Destro A, Taira K, Takeda K, Okabe T, Swanson J, Itoh H, Takada M, Lifshits E, Okuno K, Engelman JA, Shivdasani RA, Nishio K, Fukuoka M, Varella-Garcia M, Nakagawa K, Janne PA (2011) Activation of ERBB2 signaling causes resistance to the EGFR-directed therapeutic antibody cetuximab. Sci Transl Med 3:99ra86

Yoon J, Koo KH, Choi KY (2011) MEK1/2 inhibitors AS703026 and AZD6244 may be potential therapies for KRAS mutated colorectal cancer that is resistant to EGFR monoclonal antibody therapy. Cancer Res 71:445-453

Young KH, Baird JR, Savage T, Cottam B, Friedman D, Bambina S, Messenheimer DJ, Fox B, Newell P, Bahjat KS, Gough MJ, Crittenden MR (2016) Optimizing timing of immunotherapy improves control of tumors by hypofractionated radiation therapy. PLoS ONE 11:e0157164

Yu P, Lee Y, Liu W, Chin RK, Wang J, Wang Y, Schietinger A, Philip M, Schreiber H, Fu YX (2004) Priming of naive T cells inside tumors leads to eradication of established tumors. Nat Immunol 5:141-149 
Yu P, Lee Y, Wang Y, Liu X, Auh S, Gajewski TF, Schreiber H, You Z, Kaynor C, Wang X, Fu YX (2007) Targeting the primary tumor to generate CTL for the effective eradication of spontaneous metastases. J Immunol 179:1960-1968

Zhu EF, Gai SA, Opel CF, Kwan BH, Surana R, Mihm MC, Kauke MJ, Moynihan KD, Angelini A, Williams RT, Stephan MT, Kim JS, Yaffe MB, Irvine DJ, Weiner LM, Dranoff G, Wittrup KD (2015)
Synergistic innate and adaptive immune response to combination immunotherapy with anti-tumor antigen antibodies and extended serum half-life IL-2. Cancer Cell 27:489-501

Zou W, Zheng H, He TC, Chang J, Fu YX, Fan W (2012) LIGHT delivery to tumors by mesenchymal stem cells mobilizes an effective antitumor immune response. Cancer Res 72:2980-2989 